\title{
Optimal board size in the Jordanian banks: Empirical evidence based on accounting performance
}

\author{
Mohammad Ahid Ghabayen \\ Institute of Public Administrative \\ Riyadh, Kingdom of Saudi Arabia \\ Zaid Jaradat \\ Ahmad Hardan \\ Mohannad Obeid Al-Shbail \\ University Malaysia Terengganu, Kuala Terengganu, Malaysia
}

\begin{abstract}
Keywords
Optimal Board Size - Accounting Performance - Jordan - Banks.
\end{abstract}

\begin{abstract}
The aim of this paper is to examine the optimal board size in the Jordanian banking sector with a focus on the accounting performance using a panel data from 2004 to 2013. In general, we find that the board size and bank performance are related but not at a significant level. Interestingly, we find that neither too small boards nor too large boards are effectively enhancing the bank accounting performance. The study concludes that the optimal board size is between 9 to 12 directors. Boards with less than nine directors are found to be insignificantly related to the bank performance while boards with more than 12 members are significantly and negatively related to the performance. Currently, the corporate governance codes suggest the board to be at least five directors and not more than 13 directors. Thus, this study suggests the policy makers to limit the size of the board to 9-12 directors only.
\end{abstract}

Corresponding author: Mohammad Ahid Ghabayen

Email address for corresponding author: Mohammadahed83@yahoo.com

First submission received: $18^{\text {th }}$ December 2017

Revised submission received: $5^{\text {th }}$ February 2018

Accepted: $20^{\text {th }}$ March 2018

\section{Introduction}

Board size is an issue of the board characteristics that has been often discussed in the corporate governance studies. Raheja (2005) pointed out that advising and monitoring are the two main functions of the board of directors. The size of the board has significant impacts on the level of controlling, monitoring and information disclosure. Prior studies have searched the determinants of board size (Chaganti, Mahajan \& Sharma, 1985; Akhtaruddin, Hossain \& Hossain, 2009). Yermack (1996) concluded that the firm size determines the board size. In addition to the firm size, Boone et al. (2007) stated that the size of the board grows with the growing and diversifying of the firms. They concluded that firm tradeoff between the advantages and the costs of monitoring to determine the size of the board.

Board size has been examined extensively and the issue of the optimal board size is still researchable due to the inconsistent perspective either theoretically or empirically. From agency theory perspective, it is argued that small board size is expected to be better because fewer members in the board are likely to be more dynamic and active, as well as, it is easier in the small board to reach consensus (Jensen, 1993). Furthermore, boards with fewer members monitor the firms and control the managements more effectively while large board face coordination problems and director free-riding (Lipton \& Lorsch; 1992; Jensen, 1993). Kim, Nofsinger and Mohr (2009) argued that members in small boards exert more effort because they all realize their monitoring function in the firm. In addition, boards with larger directors may negatively impact the process of decision making (Jensen, 1993) and mitigates their effectiveness in monitoring top managers (Yermack, 1996). 
On the other hand, resource dependency theory argues that larger boards are more likely to consist of experts and specialists, which may result in increasing the company value and enhancing the decision-making procedures (Chaganti et al., 1985; Dalton et al., 1998; Dalton et al., 1999; Dallas, 2001; Abeysekera, 2010). In addition, greater number of directors in the board might be a better monitoring tool because they will have the ability to perform their function more effectively (Zahra \& Pearce, 1989; Hillman \& Dalziel, 2003). Furthermore, more directors in the board may have better ability to solve the problems facing the company due to the varied directors' viewpoints.

The main role of the board of directors is to monitor the top managements. This role has been examined extensively and the findings are inconsistent, but the consensus indicated the small boards are monitoring more effectively (Jizi et al., 2013). Boards with fewer directors are more productive and more cohesive and active while the large board size is seen as over-sized boards (Lipton \& Lorsch, 1992; Jensen, 1993). On the other side, resource dependency theory views the board of directors as resources providers. Thus, more directors in the board may provide the firm with more resources.

Thus, both theoretical views can be critical when it comes to the accounting performance. That is, the monitoring and controlling functions are assumed to enhance the firm performance. In the same line, providing the firms with the important resources may lead to better performance. Empirically, board size is found to be associated with firm performance (Yermack, 1996; Eisenberg et al., 1998; Kiel \& Nicholson, 2003). The association between board size and firm performance has been extensively examined and they have showed mixed results. Notwithstanding the majority of the previous studies found that board size has a negative impact on the firm performance (e.g., Jensen, 1993; Barnhart \& Roseinstein, 1998; Mak \& Li, 2001; Van Ees et al., 2003; Adams \& Mehran, 2005; Cheng et al., 2008; Shakir, 2008; Guest, 2009), some other studies found a positive relationship (e.g., Hermalin \& Weisbach, 2003; Bonn, Yoshikawa \& Phan, 2004; Haniffa \& Hudaib, 2006). Furthermore, some empirical studies do not find any association between board size and firm performance (Chaghadari, 2011; Topak, 2011; Ghabayen, 2012).

The focus of this study is to examine the applicability of agency theory and resource dependency theory on the Jordanian banking industry. More precisely, this study examines the relationship between board size and bank performance. The results of this study significantly contribute to the body of knowledge. We find that neither too small boards nor too large boards are effectively enhancing the bank accounting performance. The study concludes that the optimal board size is between 9 to 12 directors. Boards with less than nine directors are found to be insignificantly related to the bank performance while boards with more than 12 members are significantly and negatively related to the performance. Currently, the corporate governance codes suggest the board to be at least five directors and not more than 13 directors. Thus, this study suggests the policy makers to limit the size of the board to 9-12 directors only.

The subsequent sections are organized as follows: the second section reviews the board size/performance relationship following with the research methodology in the third section. Section four presents the procedure of the data analysis. Results and discussion are discussed in section five while the conclusion and future works are presented in the final section.

\section{Board size and performance}

A firm's board size refers to the number of firm's directors serving in the board of directors (Jensen \& Meckling, 1976). Roles of board size have been a controversial issue from different theoretical views. Lipton and Lorsch (1992) and Jensen (1993) suggested that the board size should be limited to seven or eight members only. In the developed countries, Lipton and Lorsch (1992) examined the US board size and their study indicated that the US firms have crowded boards which might result in increasing the cost to the shareholders, reducing the competitive opportunities in the market and causing the employees to lose their jobs. They concluded that the board size should consist of a maximum eight directors and if the board has more than 10 members they will not perform effectively because they will face a communication problem during the meetings such as the difficulty in expressing their ideas and opinions.

Besides, Jensen (1993) argued that the functions of the board will be reduced in a large board size, more than eight directors, because it is difficult for the board to manage the meetings or to reach to a consensus. Furthermore, he argued that the large board size is easier to be controlled by the CEO. In the 
same vein, Topak (2011) concluded that board with more directors is more costly and it affects the decision making procedures, communication and coordination between directors in the board. Furthermore, in comparison with large board size, boards with few directors have superior performance (Barnhart \& Rosenstein, 1998). Based on the agency theory, larger companies need larger boards to control and to monitor the management actions. This means that the size of the firm is an influential factor that determines the board of directors' size. This viewpoint has been empirically supported by many authors. Coles et al. (2008) pointed out that large and complex firms, which have diversified businesses, need more members in their board because they need more advising requirements. Dalton et al. (1999) pointed out that larger boards are likely to consist of more experts and knowledgeable directors and offer better advice to the CEO. This indicated that complex firms need larger boards. Many members in the boards may enhance director's board to perform their roles more effectively.

Focusing in the board size/bank performance relationship, different studies have been conducted in this area with mixed results. Grove et al. (2011) found that banks with smaller boards outperform their counterparts during the global financial crisis in a sample of 236 US public commercial banks from 20052008. Moreover, using a sample of 74 listed banks of Gulf Council Countries (GCC) except Kuwaiti listed banks during the period 2008-2010, Al-Musalli and Ismail (2012) reported that board size and intellectual capital performance are negatively associated. More recently, Naushad \& Abdul Malik (2015) found that smaller boards are more effective in monitoring the management in GCC. Some other studies found that the board size is not significantly related to the firm performance in the GCC region such as in UEA (ALJifri \& Moustafa, 2007), Saudi Arabia (Al-Matari et al., 2012; Ghabayen 2012) and Kuwait (Al-Matari et al., 2013).

In conclusion, the issue of the board size has been extensively investigated and the optimal board size is not yet under the focus of the majority of the previous studies. In the context of the firm performance, the focus of the previous studies was to examine the board size-firm performance relationship. Thus, this study is an attempt to test one-sit-fits-all concept. First of all, it examines the board size-performance relationship in the Jordanian banking industry. Secondly, it attempts to examine the optimal board size. If small (large) board size is better, to which extent small (large) board size can be effective? Thus, the following hypotheses are developed:

$\mathrm{H}_{1}$ : there is a positive relationship between board size and bank performance.

$\mathrm{H}_{2}$ : very small (large) boards are ineffective in improving the bank performance.

\section{Research methodology \\ Sample and data collection}

The banking industry in Jordan is well-organized and it follows the roles of different acts such as Banking Acts (2006) companies Law $(1997,2006)$ and corporate governance regulations (2007). The banking sector in Jordan has its own characteristics. That is, the banks are either to be publicly listed or affiliated bank or offshore company (Jordanian Bank Act, 2006, Article, 6). In addition, in terms of activities, the banks in Jordan may operate their businesses either based on the Islamic rules (Islamic banks) or conventional rules (conventional banks) but not a mixture. In Jordan, there are 16 local banks operating in the country. Some of them have branches in the Arabic region (regional banks) and some other banks have international orientation. From the 16 Jordanian banks, 15 banks are traded in the Amman Stock Exchange (ASE). In other words, one of the banks is totally owned by another bank (affiliated bank). In addition, out of the 16 banks, there are three Islamic banks. The focus of this study is the conventional banks. Islamic banks are excluded in this study. As their activities are different, their characteristics and institutional structure are also believed to be different.

The data of this study includes the 13 local conventional banks. In collecting the data, this study uses secondary sources. Secondary data includes both qualitative and quantitative and can be used for both descriptive and explanatory studies (Kervin, 1999). It is also considered as an interpretation of primary data (Cooper \& Schindler, 2003). Secondary data is referred to the data that already exists such as annual reports, published statistics, books and internal reports kept by the firms (Veal, 2005). Recently, firms issue other reports in a frequently basis such as corporate governance reports. In this study, the banks' annual reports, banks' corporate governance are the main source to gather the data. The annual 
reports are downloaded from either the banks' websites or from ASE (http://www.ase.com.jo/). In the case of unpublished annual reports, they are collected manually from the banks. In general, out of 130 annual reports, the study could collect 123 annual reports; 115 annual reports were downloaded online while eight annual reports were collected manually from the banks. However, seven annual reports were missing. The procedures of data collections are summarized in Table 3.1. Furthermore, the data of this study is collected from the Jordanian conventional banks in a period of 10 years (2004-2013).

Table 3.1 Summary of the sample

\begin{tabular}{ll}
\hline Expected Sample & $160(16$ banks 10 years $)$ \\
Islamic Banks & $(30)(3$ banks*10 years $)$ \\
Possible sample size & 130 banks \\
Missing data & $(7)$ \\
\cline { 2 - 2 } Final sample size & 123 banks/year \\
\hline Online-downloaded annual reports & 115 annual reports \\
Hand-collected annual reports & 8 annual reports \\
\cline { 2 - 2 } Total collected annual reports & 123 annual reports
\end{tabular}

Research model and measurement of the variables

In order to examine board size/performance relationship, the following regression model is utilized:

PROFT $_{i t}=a 0+\beta_{1}$ BSIZ $_{\mathrm{it}}+\beta_{2}$ LOGSIZ $_{\mathrm{it}}+\beta_{3} \mathrm{LEV}_{\mathrm{it}}+\varepsilon_{\mathrm{it}}$

Where;

PROFT: is the bank profitability, which is the bank financial performance, measured by the return on assets (ROA) which is earnings before tax divided by total assets. Similar measurement was used in the previous studies (e.g. Ghabayen, 2012; Al-Matari et al., 2012; Saibaba \& Ansari, 2013).

BSIZ: is the size of the board of director measured by the number of directors serving in the board. This measurement is widely used in the previous studies (e.g. Yermach, 1996; Kiel \& Nicholson, 2003; AlMatari et al., 2012; Ghabayen, 2012).

LEV: is leverage and it is the ratio of the book value of long-term debt divided by total assets (Anderson \& Reeb, 2003; Alsaeed, 2006; Al Matari et al., 2013; Amran \& Che-Ahmad, 2013).

LOGSIZ: is the natural log of the total assets. This measurement is widely used in the previous studies (e.g. Liu, Ahlstrom \& Yeh, 2006; Amran \& Che-Ahmad, 2013; Ibrahim \& Samad, 2013; Jizi et al., 2013; ElChaarani, 2013).

it: period indicator

$\varepsilon$ : Error Term.

Data analysis

Descriptive analysis

Table 4.1 presents the descriptive analysis of the model. Relatively, low level of ROA is found in the Jordanian conventional banks with a mean of two per cent. In addition, some banks have recorded losses in their activities. In respect to board size, the Jordanian banks have relatively large boards with a mean of almost 11 directors. The largest boards have a maximum of 13 directors while the smallest ones have seven directors. In other words, all the banks have complied with the Jordanian corporate governance guidelines which recommend 13 directors as a maximum of the board size and five directors in minimum.

\begin{tabular}{lllll}
\multicolumn{5}{c}{ Table.4.1 Descriptive Analysis } \\
\hline & ROA & BSIZ & LOGSIZ & LEV \\
\hline Mean & 0.02 & 10.7 & 21.1 & 0.86 \\
Median & 0.02 & 11 & 20.9 & 0.86 \\
SD & 0.01 & 1.64 & 1.1 & 0.33 \\
Max & .06 & 13 & 24.3 & 0.96 \\
Min & -.01 & 7 & 19 & 0.78 \\
Skewness & 0.8 & -0.78 & 1.258 & 0.87 \\
Kurtosis & 5.0 & 3.15 & 4.84 & 2.91 \\
Observations & 123 & 123 & 123 & 123 \\
\hline
\end{tabular}

www.jbrmr.com A Journal of the Academy of Business and Retail Management (ABRM) 


\section{Panel data}

Prior to run the data, we employ different diagnostics tests such as normality, heteroscedasticity, autocorrelation and multicollinearity tests to ensure unbiased results. Normality is "degree to which the distribution of the sample data corresponds to a normal distribution" (Hair et al., 2010). The most common normality tests are skewness and kurtosis. Kline (1998) recommended the data to be normally distributed if the skewness and kurtosis are between \pm 3 and \pm 10 respectively. All the variables of this study fill in the range of Kline as shown in Table 4.1.

To test the heteroscedasticity, Modified Wald test is employed as suggested by Greene (2000). STATA 10 provides a written command ( $x$ ttest3) to check for heteroscedasticity. The result of the statistical test is distributed Chi-squared $(\mathrm{N}-\mathrm{g})$ under the null hypothesis of homoscedasticity. Thus, the null hypothesis is rejected if the $p$ value is lower than 0.05 . Failure of rejecting the null hypothesis ensures the violations of the homoscedasticity and presence of the heteroscedasticity problems. The result of the Modified Wald test in this study accepts the hypothesis. Thus, it indicates that the data of this study is heteroscedastic.

In addition, we test for autocorrelation using Wooldridge test. The autocorrelation test (known also as serial correlation or first order correlation) is considered as one of the important assumption in multivariate analysis because it leads to a biased data and misleading results. Autocorrelation leads to a higher R-squared and smaller standard errors of the coefficients. The autocorrelation test is conducted with the help of $x$ tserial in STATA 10. It employs a test of serial correlation of a linear panel-data model's specification errors (Wooldridge, 2002). The result of the Wooldridge test shows a presence of autocorrelation. Thus, we use Drisc/Kraay standard errors $(x t s c c)$ to solve the both problems as suggested by (Driscoll \& Kraay, 1998). The $x t s c c$ command is suitable for both balanced and unbalanced panel data. In addition, it handles missing values.

In panel data, Hausman test is employed to decide either fixed effect model or random effect model is more appropriate to be used in the study (Greene, 2011). The null hypothesis postulates that the unique errors are not correlated with the regressors. Thus, if the P-value is not significant (Prob $>$ Chi2 is more than 0.05), the null hypothesis will be accepted, and the random effect is more appropriate to be used in the study. However, if the P-value is significant (Prob>Chi2 is less than 0.05), the null hypothesis will be rejected, and the hypothesis will be accepted. This means that the unique errors are correlated with the regressors. Thus, this indicates the appropriation of the fixed effect. Interestingly, if the hausman specification test is significant (specified the use of fixed effect), Torres-Reyna, (2007) suggests testing the model to be checked for the effects of the year. STATA 10 provide a written command (testparm i.year*) to check the effect of the time period. In all our models, the time period has significant effects on explaining the models. In the main model (model 1) the $\mathrm{R}^{2}$ was $15.33 \%$ and became $48.22 \%$. Means, the time period explains almost $33 \%$ of the relationship. Also, almost the same effects are in the other three models.

\section{Results and discussion}

The results of the multivariate analysis are presented in the Table 5.1. In the main model (model 1), the board size has insignificant effects of the performance measured by ROA. Thus, increasing (decreasing) the number of director dose not enhance (destroy) the bank performance. This leads to a general conclusion of the ineffectiveness of the board of directors in the Jordanian banking sector. Similar results were found in the Arabic region such as in UEA (ALJifri \& Moustafa, 2007), Saudi Arabia (AlMatari et al., 2012; Ghabayen, 2012) and Kuwait (Al-Matari et al., 2013). Alternatively, we rerun different models to examine the optimal board size in the Jordanian banks.

As discussed in the descriptive analysis, the size of the Jordanian conventional banks is varied from seven to 13 directors. Hence, we measure the board size as dummies. We categorize the boards based on their sizes. The first category contains the smallest boards of the sample; seven and eight directors, the results indicate negative and insignificant effects (model 2). The second category (model 3) contains the moderated sizes; 9, 10, 11 and 12 directors. The banks with moderated board size are found to outperform other banks. The results of the third model show a significant positive relationship between board size and bank performance. The third category presents the crowded boards; boards with 13 directors (model 4). The results of the fourth model show significant negative effects of the crowded 
boards on the bank performance. This indicates that the crowded boards may suffer from communication and cooperation issues as discussed previously by Lipton and Lorsch (1992).

Table 5.1 Multivariate Analysis

\begin{tabular}{|c|c|c|c|c|c|c|c|c|}
\hline \multirow{2}{*}{ Variables } & \multicolumn{2}{|c|}{ Model (1) } & \multicolumn{2}{|c|}{ Model (2) } & \multicolumn{2}{|c|}{ Model (3) } & \multicolumn{2}{|c|}{ Model (4) } \\
\hline & Coef & $\mathrm{t}$ & Coef & $\mathrm{t}$ & Coef & $\mathrm{t}$ & Coef & $\mathrm{t}$ \\
\hline Constant & 0.067 & 0.90 & 0.068 & 1.01 & 0.066 & 1.01 & 0.072 & 1.14 \\
\hline Board Size & 0.0002 & 0.21 & -.0017 & -1.00 & 0.003 & $2.48^{*}$ & -0.003 & $-2.85^{*}$ \\
\hline Leverage & -0.071 & $-3.54^{* *}$ & -0.072 & $-3.61^{* *}$ & -0.071 & $-3.55^{* *}$ & -0.070 & $-3.50 * *$ \\
\hline Bank Size (log) & .0006 & 0.19 & .0006 & 0.22 & .0006 & 0.21 & 0.0004 & 0.15 \\
\hline Years & \multicolumn{2}{|l|}{ Included } & \multicolumn{2}{|c|}{ Included } & \multicolumn{2}{|c|}{ Included } & \multicolumn{2}{|c|}{ Included } \\
\hline Observations & \multicolumn{2}{|l|}{123} & \multicolumn{2}{|c|}{123} & \multicolumn{2}{|c|}{123} & \multicolumn{2}{|l|}{123} \\
\hline Modified Wald test & \multicolumn{2}{|l|}{0.000} & \multicolumn{2}{|l|}{0.0000} & \multicolumn{2}{|l|}{0.0000} & \multicolumn{2}{|l|}{0.0000} \\
\hline Wooldridge test & \multicolumn{2}{|l|}{0.0377} & \multicolumn{2}{|l|}{0.0366} & \multicolumn{2}{|l|}{0.0136} & \multicolumn{2}{|l|}{0.0360} \\
\hline Prob $>$ F & \multicolumn{2}{|l|}{0.0000} & \multicolumn{2}{|l|}{0.0000} & \multicolumn{2}{|l|}{0.0000} & \multicolumn{2}{|l|}{0.0000} \\
\hline Hausman Test & \multicolumn{2}{|l|}{0.0000} & \multicolumn{2}{|l|}{0.0000} & \multicolumn{2}{|l|}{0.0000} & \multicolumn{2}{|l|}{0.0000} \\
\hline $\mathrm{R}^{2}$ (within) & \multicolumn{2}{|l|}{48.22} & \multicolumn{2}{|l|}{48.29} & \multicolumn{2}{|l|}{48.62} & \multicolumn{2}{|l|}{48.57} \\
\hline
\end{tabular}

Notes: $* *$ and $*$ is the significance level at $1 \%$ and $5 \%$ respectively.

Board size is measured as number of director serving in the board in model (1), dummy variable equal to 1 if the board is small (7 or 8 directors) and zero otherwise in model (2), dummy variable equal to 1 if the board size is moderated (9-12 directors) and zero otherwise in model (3), and dummy variable equal to 1 if the board is crowded (13 directors) and zero otherwise in model (4).

In general, the size of the Jordanian boards is relatively large. It is believed that large boards are more effective in monitoring the management, but too large boards may lose their effectiveness (Siregar \& Bachtiar, 2010). One of the main reasons that could be behind the ineffectiveness of the board in Jordan is the ownership structure. The ownership in Jordan is concentrated in few hands of owners and normally institutional investors. Thus, many directors will represent the institutional investors in the boards (Ghabayen, Mohamad \& Ahmad, 2015). As a result, it can be argued that the Jordanian banks are wellmanaged and supervised. In addition, the function of the boards might be focused on the advising and provide resources rather than monitoring the top managements. Therefore, it can be said that the conflicts between managers and owners are well-aligned. But, however, it might be shifted to the majorityminority conflicts. Notwithstanding the insignificant impact of the board size on the bank performance, the positive direction of the relationship (even it is not significant) may indicate a positive role of the board size on the bank performance and this impact is reversed when reaching a certain size (13 directors). The empirical results indicate that the boards lose their effectiveness when it is very large.

Furthermore, small boards ( 7 or 8 directors) are found to be ineffective in enhancing the bank performance. This might be due to the high workload of the directors which may lead to ineffective monitoring function (John \& Senbet 1998). In addition, smaller boards might have small pools of expertise resulting in ineffective advising and monitoring (Guest, 2009). Another reason that could be behind the ineffective of small boards is the complexity of the banks' activities. Previous studies suggested that the firm size, industry type and businesses' complexity are the main determinants of the board size (Krishnan \&Visvanathan, 2009; Pathan, 2009). Banks are considered as complex organizations because they are subject to various regulations (Grove et al. 2011). Furthermore, banks are considered as a link between the financial resources and the other economic sectors. Thus, financing other sectors may require the banks to have larger boards to acquire good pools of expertise. Therefore, larger boards are found to function more effectively in advising the top management and, therefore, the board of directors will be designed in the purpose of providing the banks with different resources such as accesses to financial and information resources.

Effective boards focus on both monitoring and advising functions. Thus, effective boards are therefore supposed to enhance the banks performance. In a business environment with a concentrated ownership such as in Jordan and other developing countries, the ownership might be a good tool to align the interest between managers and owners as suggested by Barako et al. (2006). In other words, the ownership structure may align the managers/owner's conflicts. But, however, the conflicts might be shifted from managers-owners to majority-minority. Therefore, the board of directors can be proposed as 
a good tool to align the interests between majority-minority. The boards are assumed to be designed and structured to protect the interests of the shareholders (Fama, 1980; Hermalin \& Weisbach, 1998, 2003). Thus, effective boards might set the banks' agendas and strategies in the best interests of the banks. In the case of the Jordanian banking sector, the board with moderated size is found to be more effective in enhancing the bank performance. The communications and discussions can be more fruitful when the board is not crowded. Furthermore, the monitoring function can be efficient if the board is not small due to the complexity of the banking operations.

\section{Conclusion and Future Studies}

This study is conducted in Jordan with a focus on the banking industry. The main aims of this paper are to examine the relationship between board size and bank performance in addition to attempt to find the optimal board size for the Jordanian conventional banks. The results of the panel data indicated insignificant relationship between board size and bank performance which is similar to the majority of the previous studies in the Arabic region. Thus, we categorize the board size into three categories; small boards ( 7 and 8 directors), moderated boards (9-12 director) and crowded board (13 directors). Neither small boards nor crowded board are effective in enhancing the bank performance. Larger boards are found effective in enhancing the bank performance, but this positive impact is reversed when reaching a certain size (13 directors). Too large boards may have more conflicts resulting in focusing on selfinterested objectives. Due to the bank size and the complexity of their operations, the banks need relatively larges boards and small boards are found to be ineffective in improving the performance.

This study has different theoretical and practical implementations. Theoretically, adopting the agency theory in the banking sector might be critical due to the complexity of the banks' operations. Thus, larger boards might be more effective in monitoring (agency theory) and providing resources to the banks (resource dependency theory). Practically, the code of corporate governance in the Jordanian banks suggests the banks to have boards with 5-13 directors. However, the empirical results of this study find that boards with less than 9 directors are ineffective related to the bank performance. In addition, too large boards (13 boards) are negatively related to performance. Thus, policy makers and the conventional banks in Jordan may consider a moderated board size when designing their boards. Further studies may consider the experience of the director as one of the possible tools for the effectiveness of the bank performance. In addition, other studies may focus on the board diversity such as the independence level, female directors and nationality. Further, the ownership structure may moderate the relationship between firm performance and the board characteristics.

\section{References}

Abeysekera, I., 2010. The role of corporate governance in intellectual capital disclosure of Kenyan listed firms. Journal of Intellectual Capital, 11(4), 14.

Adams, R. B., \&Mehran, H., 2005.Corporate performance, board structure and its determinants in the banking industry, in EFA 2005 Moscow Meetings.

Akhtaruddin, M., Hossain, M. A., Hossain, M., \& Yao, L., 2009. Corporate governance and voluntary disclosure in corporate annual reports of Malaysian listed firms. Journal of Applied Management Accounting Research, 7(1), 119.

Aljifri, K., \&Moustafa, M., 2007. The impact of corporate governance mechanisms on the performance of UAE firms: an empirical analysis. Journal of economic \& administrative Sciences, 23(2), 71-93.

Al-Matari, E. M., Al-Swidi, A. K., Fadzil, F. H., \& Al-Matari, Y. A., 2012. The Impact of board characteristics on Firm Performance: Evidence from Nonfinancial Listed Companies in Kuwaiti Stock Exchange. International Journal of Accounting and Financial Reporting, 2(2), Pages-310.

Al-Matari, Y., Al-Swidi, A., \&Fadzil, F., 2012. corporate governance and performance of Saudi Arabia listed companies. British Journal of Arts \& Social Sciences, 9, 1-30.

Al-Musalli, M. A. K., \& Ismail, K. N. I. K., 2012. Intellectual capital performance and board characteristics of GCC banks. Procedia Economics and Finance, 2, 219-226.

Alsaeed, K., 2006. The association between firm-specific characteristics and disclosure: The case of Saudi Arabia. Managerial Auditing Journal, 21(5), 476-496.

Amran, N. A., \& Ahmad, A. C., 2013. Effects of ownership structure on Malaysian companies' performance. Asian Journal of Accounting and Governance, 4, 51-60. 
Anderson, R. C., \&Reeb, D. M., 2003. Founding-family ownership and firm performance: evidence from the S\&P 500. The journal of finance, 58(3), 1301-1328.

Barako, D. G., Hancock, P., \&Izan, H. Y., 2006. Factors influencing voluntary corporate disclosure by Kenyan companies. Corporate Governance: An International Review, 14(2), 107-125.

Barnhart, S. W., \& Rosenstein, S., 1998. Board composition, managerial ownership, and firm performance: An empirical analysis. Financial Review, 33(4), 1-16.

Bonn, I., Yoshikawa, T., \&Phan, P.H., 2004. Effects of board structure on firm performance: A comparison between Japan and Australia. Asian Business \& Management 3,105-125.

Boone, A. L., Casares Field, L., Karpoff, J. M., \&Raheja, C. G., 2007. The determinants of corporate board size and composition: An empirical analysis. Journal of Financial Economics, 85(1), 66-101.

Chaganti, R. S., Mahajan, V., \& Sharma, S., 1985. Corporate board size, composition and corporate failures in retailing industry. Journal of Management Studies, 22(4), 400-417.

Chaghadari, F,M., 2011. Corporate governance and firm performance. International Conference on Sociality and Economics Development, 10, 484- 489.

Cheng, S., Evans, J.H., \&Nagarajan, N. J., 2008. Board size and firm performance: The moderating effects of the market for corporate control, Review of Quantitative Finance and Accounting, 31(2), 121-145.

Coles, J. L., Daniel, N. D., \& Naveen, L., 2008. Boards: Does one size fit all?.Journal of Financial Economics, 87(2), 329356.

Cooper, D. R., \& Schindler, P. S., 2003. Business research methods (8th ed.). Singapore: McGraw-Hill.

Dallas, L.L., 2001. Development in the US board of directors and the multiple roles of corporate.

Dalton, D. R., Daily, C. M., Ellstrand, A. E., \& Johnson, J. L., 1998. Meta-analytic reviews of board composition, leadership structure, and financial performance. Strategic Management Journal, 19(3), 269-290.

Dalton, D. R., Daily, C. M., Johnson, J. L., \&Ellstrand, A. E., 1999. Number of directors and financial performance: A meta-analysis. Academy of Management journal, 42(6), 674-686.

Driscoll, J. C., \&Kraay, A. C., 1998. Consistent covariance matrix estimation with spatially dependent panel data. Review of economics and statistics,80(4), 549-560.

Eisenberg, T., Sundgren, S., \& Wells, M. T., 1998. Larger board size and decreasing firm value in small firms. Journal of financial economics, 48(1), 35-54.

El-Chaarani, H., 2013. The success keys for family firms: A comparison between Lebanese and French systems. Journal of Business and Retail Management Research, 8(1).

Fama, E. F., 1980. Agency problems and the theory of the firm. The Journal of Political Economy, 288-307.

Ghabayen, M. A., 2012. Board characteristics and firm performance: Case of Saudi Arabia. International Journal of Accounting and Financial Reporting,2(2), Pages-168.

Ghabayen, M.A., Raihan. N.M., \&Norsiah. A., 2016. Board characteristics and corporate social responsibility disclosure in the Jordanian banks. Corporate Board: role, duties and composition, 12 (1).

Greene, W. H., 2000. Econometric analysis (International edition).

Grove, H., Patelli, L., Victoravich, L. M., \& Xu, P. T., 2011. Corporate governance and performance in the wake of the financial crisis: Evidence from US commercial banks. Corporate Governance: An International Review,19(5), 418436.

Guest, P.M., 2009. The impact of board size on firm performance: evidence from the UK. The European Journal of Finance 15(4),385-404.

Hair, J. F., Black, W. C., Babin, B. J., Anderson, R. E., \& Tatham, R. L., 2010. Multivariate data analysis.

Haniffa, R., \&Hudaib, M., 2006. Corporate governance structure and performance of Malaysian listed companies. Journal of Business Finance $\mathcal{E}$ Accounting, 33(7-8), 1034-1062.

Hermalin, B. E., \&Weisbach, M. S., 2003. Boards of directors as an endogenously determined institution: A survey of the economic literature. Economic Policy Review - Federal Reserve Bank of New York, 9, 7-26.

Hermalin, B. E., \&Weisbach, M. S., 2003. Boards of directors as an endogenously determined institution: A survey of the economic literature. Economic Policy Review - Federal Reserve Bank of New York, 9, 7-26.

Hillman, A. J., \& Dalziel, T., 2003. Boards of directors and firm performance: Integrating agency and resource dependence perspectives. Academy of Management review, 28(3), 383-396.

Ibrahim, H., \&Samad, F. A., 2011. Agency costs, corporate governance mechanisms and performance of public listed family firms in Malaysia. South African Journal of Business Management, 42(3).

Jensen, M. C., \&Meckling, W. H., 1976. Theory of the firm: managerial behavior, agency costs and ownership structure. Financial Economics, 3, 305-360.

Jensen, M., 1993. The modern industrial revolution, exit, and the failure of internal control systems. Journal of Finance, July 1993, 48(3), 831-880. 
Jizi, M. I., Salama, A., Dixon, R., \&Stratling, R., 2014. Corporate governance and corporate social responsibility disclosure: evidence from the US banking sector. Journal of Business Ethics, 125(4), 601-615.

John, K., \&Senbet, L. W., 1998. Corporate governance and board effectiveness. Journal of Banking E Finance, 22(4), 371403.

Kervin, B., 1999. Methods for business research. (2nded.). New York: HarperCollins.

Kiel, G. C., \& Nicholson, G. J., 2003. Board composition and corporate performance: How the Australian experience informs contrasting theories of corporate governance. Corporate Governance: An International Review, 11(3), 189205.

Kim, K.A., Nofsinger, J.R. and Mohr, D.J., 2009. Corporate Governance, Third Edition, Pearson.

Kline, R. B., 1998. Principles and practices of structural equation modeling. New York: Guilford.

Krishnan, G., \& Visvanathan, G., 2009. Do auditors price audit committee's expertise? The case of accounting versus nonaccounting financial experts. Journal of Accounting, Auditing E Finance, 24(1), 115-144.

Lipton, M. \&lorsch, J. W., 1992. A modest proposal for improved corporate governance. Business Lawyer, 48(1), 59-77.

Liu, Y., Ahlstrom, D., \&Yeh, K. S., 2006. The separation of ownership and management in Taiwan's public companies: An empirical study. International Business Review, 15(4), 415-435.

Mak, Y. T. \& Li, Y., 2001. Determinants of corporate ownership and board structure: Evidence from Singapore. Journal of Corporate Finance, 7(3), 236-256.

Naushad, M., \& Malik, S. A., 2015. Corporate Governance and Bank Performance: A Study of Selected Banks in GCC Region. Asian Social Science, 11(9), 226.

Pathan, S., 2009. Strong boards, CEO power and bank risk-taking. Journal of Banking E Finance, 33(7), $1340-1350$.

Raheja, C., 2005. Determinants of board size and composition: a theory of corporate boards. Journal of Financial and Quantitative Analysis 40(2), 283-306.

Saibaba, M. D., \& Ansari, V. A., 2013. Audit committees, board structures and firm performance: a panel data study of BSE 30 companies. IUP Journal of Accounting Research \& Audit Practices, 12(2), 19.

Shakir, R., 2008. Board size, executive directors and property firm performance in Malaysia. Pacific Rim Property Research Journal, 14(1), 1-16.

Topak, I, T., 2011. The Effect of Board Size on Firm Performance: Evidence from Turkey. Middle Eastern Finance and Economics. 14. 119-127.

Torres-Reyna, O., 2007. Panel data analysis fixed and random effects using Stata (v. 4.2). Data E Statistical Services, Priceton University.

Van Ees, H., Postma, T. J., \&Sterken, E., 2003. Board characteristics and corporate performance in the Netherlands. Eastern Economic Journal, 41-58.

Veal, A. J., 2005. Business research methods: A managerial approach. Pearson Education Australia/Addison Wesley.

Veronica Siregar, S., \&Bachtiar, Y., 2010. Corporate social reporting: empirical evidence from Indonesia Stock Exchange. International Journal of Islamic and Middle Eastern Finance and Management, 3(3), 241-252.

Wooldridge, J. M., 2002. Econometric analysis of cross section and panel data. Cambridge, MA: MIT Press

Yermack, D., 1996. Higher market valuation of companies with a small board of directors. Journal of Financial Economics 40, 185-212.

Zahra, S. A., \& Pearce, J. A., 1989. Boards of directors and corporate financial performance: A review and integrative model. Journal of management, 15(2), 291-334. 